НОВІ МЕДІА

Visn. Lviv. Univ., Ser. Zhurn. 2019: 45; 351-359 • DOI: http://dx.doi.org/10.30970/vjo.2019.45.10018

УДК 070:323.2

SOCIAL NETWORKS AS A FACTOR OF POLITICAL MOBILIZATION

\author{
Olena Porpulit \\ Odesa I.I. Mechnikov National University, \\ Dvoryanska St, 2, Odesa, 65082, Ukraine \\ e-mail:porpulit@ukr.net \\ https://orcid.org/0000-0002-5118-305X
}

To answer the question of the form of participation used by Ukrainians before the upcoming presidential election, whether they demonstrate their participation in the political processes of the country and how there is political mobilization in social networks, we analyzed 5829 posts posted on Facebook. The conducted studies suggest that there is the formation and ripening of politically active account holders on Facebook, capable of producing, selecting and disseminating politically oriented information, creating politically colored content and controlling the transformational vicissitudes of the political process.

Key words: social networks, account, political activity, political mobilization, leisure practice.

Innovations and achievements of the last decades in technological, and as a result, in informational and communicational spheres, have brought about significant changes to the lives of millions of people. The instantaneous and «pandemic» attachment to global networks, the frequency, and prevalence in the use of mobile devices, gadgets, and devices have radically changed the formats of sharing social information. Gradually, social networks gained the status of an organic and inalienable companion of everyday life in the 21st century. In this context, taking into account the views of scholars, which are represented in multidisciplinary concepts, we offer an interdisciplinary definition of social networks: under social networks we understand special Internet technologies, the main task of which is to simplify the production and distribution of information among users in the form of participation in virtual Internet-communities. The emphasis on Internet technologies as a prerequisite for the emergence, existence, and functioning of social networks is made due to the fact that computers and mobile telecommunication devices provide access to the investigated phenomenon. When interacting with social networks, agents engage in the development and operation of multimedia, interactive platform, which in turn allows you to share, create, discuss, and modify information (content) produced by the user or groups of other users. The latest information and communication technologies have affected

$\overline{\text { (C) Порпуліт O., } 2019}$ 
political activity and political mobility of people. We regard political mobility as «a process in which, thanks to the formation of new parties and other political institutions on the political arena, broad segments of the population are derived» [5, p. 146]. On the one hand, technological changes have enabled a person to independently determine the degree of political mobility (for example, when planning the time «for himself», the actor of a social network at his discretion determines the limits of working time and free time, which can be spent on leisure, charity, political activity, and etc.). On the other hand, technological innovations are capable of changing the nature of political mobilization, by creating new types of politically active/passive practices, improving forms of participation in political decisions/events. Therefore, the study of problems and trends created by the influence of social networks on political mobilization in the new socio-cultural, informational and communication conditions is highly relevant.

The purpose of the study is to determine, based on the analysis of theoretical sources and empirical data, whether social networks are used to represent the degree of political activity among Ukrainian users of Facebook, to find out the potential of social networks in terms of political mobilization processes at the current stage of Ukrainian society development.

Social networks and network communities are the study subject for a certain number of domestic researchers: N. Bilan, B. Valuha, L. Gorodenko, D. Gubanov, D. Ivanov, S. Konoplytsky, O. Matveyeva, K. Obukhov, I. Panchenko, R. Selyesnev, Y. Skripak, O. Shevchuk, O. Chizhik etc. The problem of «political mobilization» and the issues related to it are explored by M. Holovaty, S. Danilenko, O. Kartunov, T. Kremen, L. Nagorna, O. Reznik, O. Tkach, M. Shulga, V. Tsvyh, and others. The presentation of the «political mobilization» phenomenon in sociological, political science, social and communication studies does not solve the problem, unfortunately, regarding the mobilizing potential of social networks in different processes taking place in the Ukrainian political life nowadays.

The current state of research of the social networks phenomenon is devoid of unanimity in determining their importance and weight in society. So, trying to «better understand what place is occupied by social networks in modern society» [10, p. 127], R. Seyelynev and E. Skripak find out the uniqueness of social networks' influence on society. And this uniqueness, according to researchers, lies in the ambivalence of this influence. On the one hand, the introduction of social networks contributed to the fact that random, ephemeral, unstable human contacts and connections have become permanent and sustainable. But, on the other hand, with the increase of people in the virtual world, social connections are becoming more and more fleeting and short-lived [10, p. 127]. Accordingly, the structure of the social network as a social structure is formed from a set of nodes, which are social groups, people, individuals [2, p. 29], as a result, we have a system of friends or a system of groups. The current statistical landscape of a social network allows you to observe the behavior of the audience through studying and researching its reaction to informational messages, which, appearing in the accounts of actors of the social network, belonging to one system of friends, form, so to speak, the agenda of search aggregates. By getting into the various TOPs they reflect the public mood of the population. Social networks demonstrate vectors for understanding the system of values and traditions in society, allow you to feel the tendencies of mood and preferences in the social environment. Researchers emphasize that social networks today acquired a fundamentally new meaning for society: «they are a tool for modeling human behavior and the formation of personality» [13, p. 67]. 
We are talking about the ability of a social network to organize and format its own audience in accordance with individual selection criteria, while the core of a social network would consist of individuals who share the similar and identical mood, ideas, views, and thus form a social subgroup. The activity of such a subgroup can be estimated by the number of reposts in social networks, according to the rating of the informational message in the TOP of aggregates, by the presence/absence of comments and likes.

By emphasizing the growing interest in social networks over the last decades, M. Gandaloyeva proves that this phenomenon has socio-cultural and political potential. The author singles out the properties of social networks, which prove their socio-cultural nature: the creation of a special 'virtual' culture, the generation of the «Olbanian language», the emergence of virtual addiction, a significant influence on formation and development of values, moral and ethical guidelines of youth, etc. [3, p. 19-20]. As a political phenomenon, according to M. Gandaloyeva, social networks are a relatively new tool of political communication: «New methods and technologies come into politics. Gradually, social networks become regularly used, and sometimes they become the most beloved tool of politicians» [3, p. 21]. When recognizing the potential of social networks' influence on public policy, O. Krestinina and Y. Chernyshov suggest, on the basis of the target orientation, the conditional division of the politicized groups represented in social networks into three categories: 1) communicational - aimed at the exchange of opinions; 2) informational and propagandist; 3) consolidation - association of like-minded people [7, p. 293]. At the same time, the authors note, «the most successfully implemented are consolidation, informational and propagandist functions» [7, p. 293]. Accordingly, researchers distinguish three trends in the use of social networks in the political struggle: 1) use of blogs to inform, consolidate supporters and coordinate their actions; 2) propaganda and justification of their own ideas; 3) counter-propaganda, combat against political opponents [7, p. 289]. Let's add that scientists warn against exaggeration and overestimation of the social network's role in shaping the social mood of society: joining a politicized group in a social network does not at all mean the readiness of an individual to act; Participation in a group does not necessarily involve lively discussions, detailed discussions which only shows its superficiality and fragmentation, demonstrates unnecessary subjectivity in assessing a situation/problem/ issue, etc.

Political mobilization, according to O. Bezruk, is based on political participation or political activity: «Mobilization can be considered as a manifestation of political participation or activity. As a result of a conflict, one group holds more favorable political status, the other loses or does not reach it. This is a manifestation of political mobility on the individual and group levels. At the same time, the movement of the power resource, the formation of opposition groups also symbolize the processes of political mobility» [1, p. 23]. Mobilization, according to researchers, implies a high level of participation of masses in politics, their political engagement. At the same time, the means and tricks of political engagement can be soft, convincing, argumentative, since they are oriented at clear purposes, interests, needs of citizens or harsh, coercive, motivational, which involve citizens in political participation, without paying attention on their thoughts and believes [8, p. 99]. T. Kremen interprets political mobilization «as a process of encouraging the population to participate in political action, which is not always equal to political activity» [6, p. 13]. The researcher emphasizes that from the point of view of classical political science, political mobilization is a prerequisite for the existence of any society since its level of 
stability directly depends on the level of social activity. The political mobilization of passive citizens that are not very interested in politics is a guarantee of democratic transformations in society, its progress on the way to improvement. Regardless of the task, to increase political activity of citizens or to keep them in a passive state, the political mobilization carried out by political actors aims to transform the community into a part of political process, to make every person an active figure in the political system, to create conditions for the realization of its creative potential [6, p. 13]. Researchers emphasize that the purpose of political mobilization may be not only to increase the political activity of an individual but also to nullify it; «Since apathy can be considered a form of political participation, and both of these processes are essentially a consequence of political actors' actions» [5, p. 147]. When evaluating the political participation of Ukrainian citizens in the formation of a democratic society, G. Iovchu chooses the second format of political mobilization as the most characteristic for our country: «because of this, we can see that the level of political participation of citizens is reduced, their influence on political decisions and formation of governmental institutions is restricted, there is a lack of effective mechanisms to articulate the interests of citizens or the loss of them» [4, p. 3]. In this case, some scholars are talking about the phenomenon when there is a shortage of citizens' influence on political processes, while using the term «democratic deficit» [14, p. 73]. T. Kremen in her dissertation paper «Political mobilization in the context of social media» reveals the essence of political mobilization as a process of transferring the latent opposition to the manifested form, as well as the political «minus mobilization», that is, depoliticization, which gives the opposite effect to mobilization. "Minus mobilization», as noted in the dissertation, «results in an increase in political apathy of potential voters, the spread of indifferent attitude to political activity. This type of mobilization is used in authoritarian societies and performs two tasks:

- on the one hand, to get rid of conflicts and «suppress» the opposition;

- on the other hand, to ensure the minimum consent of the population to the state policy» [6, p. 13].

Consequently, political mobilization, with the aim of transforming the public into a component of political process, involving the individual in the political life of the country, introducing examples of political behavior among the general population, may cause completely opposing situations: on the one hand, an increase in the level of citizen activity; on the other hand, strengthening of political apathy, indifference of the population. To answer the question which form of participation is used by Ukrainians before the upcoming presidential election, whether they demonstrate their participation in political processes of the country and in what way or whether political mobilization exists in social networks, we conducted research on 200 accounts of Ukrainian users on Facebook, divided into two stages:

- the first stage - during July 2016, September 2016, January 2017, March 2017 [9];

- the second stage - during September, October, November, December 2018.

We based our research on the fact that the demonstration of political activity is a voluntary choice of the owner of social network account, it is not a part of an obligatory work process, so it is represented in posts, photographs, video broadcasts that show the actor's leisure practices. We analyzed 2814 and 3015 messages posted on Facebook during the first and second stages of the study, respectively.

By summing up the modern tendencies in the scientific determination of the term «leisure», we emphasize that the main purpose of leisure is the comprehensive development of an individual: «... categories and concepts of leisure should be interpreted on the basis 
of individual cultural needs, requests, interests, preferences of an individual as a subject of cultural and leisure activities, his relation to certain forms and types of leisure activities» [12, p. 10].

Most often, personal content of a Ukrainian user of the Facebook network is filled with information on such kinds of leisure practices as tourism, outdoor recreation, visits to sports clubs, participation in social and political events, socializing, visits to sports competitions, hunting and fishing, cooking dishes, flower breeding etc. By selecting 100\% of the total number of analyzed posts, the presence of a particular leisure activity was calculated with the formula:

$$
\mathrm{NPC} \times 100 / \mathrm{GN}
$$

where NPC is the number of posts about a certain leisure activity, GN - general number of posts about leisure activities (tab. 1). Thus, during the first stage of the study, we identified 2,814 texts that represent leisure practice of the account owner; At the second stage $-3,015$ texts. Information presented in Table (1) gives an opportunity to see how the leisure priorities of Ukrainians changed during 2016-2018.

\section{Representation of leisure practices frequency by Ukrainian users on Facebook during 2016-2018}

\begin{tabular}{|c|c|c|}
\hline $\begin{array}{r}\text { Research stage } \\
\text { of leisure activity }\end{array}$ & $\begin{array}{c}\text { The first research stage } \\
\text { (2016-2017), quantitative } \\
\text { indicators, } \%\end{array}$ & $\begin{array}{c}\text { Другий етап досліджен- } \\
\text { ня (2018), quantitative } \\
\text { indicators, \% }\end{array}$ \\
\hline Tourism & 17,12 & 17,94 \\
\hline Outdoor recreation & 14,85 & 18,44 \\
\hline Participation in political events & 7,00 & 15,42 \\
\hline Visits to sports clubs & 11,09 & 7,23 \\
\hline $\begin{array}{l}\text { Visiting / taking part in sports } \\
\text { competitions }\end{array}$ & 7,71 & 6,10 \\
\hline Socializing & 7,25 & 6,53 \\
\hline Other leisure activities & 34,97 & 28,32 \\
\hline Total & $100 \%(2814$ post $)$ & $100 \%$ (3015 posts) \\
\hline
\end{tabular}

It must be mentioned that the participation of citizens in political (public-political) events increased almost twice during the studied period. The outlined situation is entirely due to political, economic and socio-cultural transformations that take place in the context of the renewal of Ukrainian society in recent years. Thus, the events of EuroMaydan, according to scientists, were a burst of public activity that spanned the general population. According to the monitoring of UISS named after O. Yaremenko with the participation of the Department for Monitoring Research of Socio-Economic Transformations from the state institution «Institute of Economics and Forecasting of NAS Ukraine». During the March 2014 poll, 21\% of respondents stated that they personally participated in mass demonstrations, $18.2 \%$ responded that members of their family participated in mass appearances, $43.9 \%$ had friends or colleagues who participated in meetings during the end of 2013 - the beginning of 2014» [11, p. 10]. 
The analysis made it possible for us to distinguish certain representation variants of political activity in the accounts of Ukrainian users on Facebook (Figure 2). The Ukrainians demonstrated their political activity by posting 197 messages in their own accounts (the first stage of the study) and 465 messages (the second stage of the study).

\section{Representation of Ukrainian users' activity on Facebook}

Figure 1.

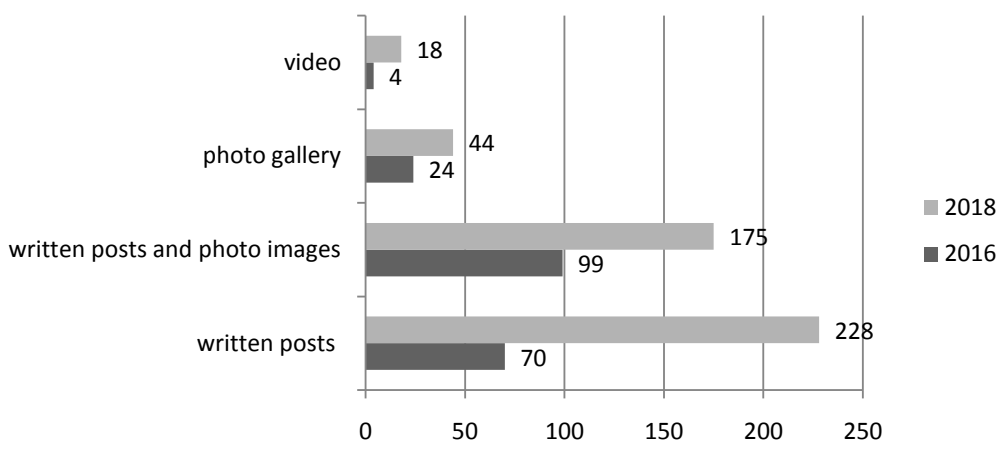

According to the data, the most active Facebook account holders post written text messages, thus, showing their political activity, expressing their support for / disagreement with certain political trends or political processes, becoming involved in political mobilization processes, and so on. We must note the gradual decrease in the number of views, comments, and transmissions, the information of which is presented along with the «statement» of the account holder (See Figure 2). The key point is the fact that, over time, actors of social networks come to recognize the ability of Internet initiatives to spray social activism when nominal engagement becomes only a simulation of social initiative and «falsification» of solidarity actions. Moreover, the formation of our own account content due to reposts of likeminded people's «statements» allows the actor of a social networks «to become» a political activist and spokesman for solidarity initiatives without significant time loss.

\section{Level of civic activity during the researched period}

Figure 2.

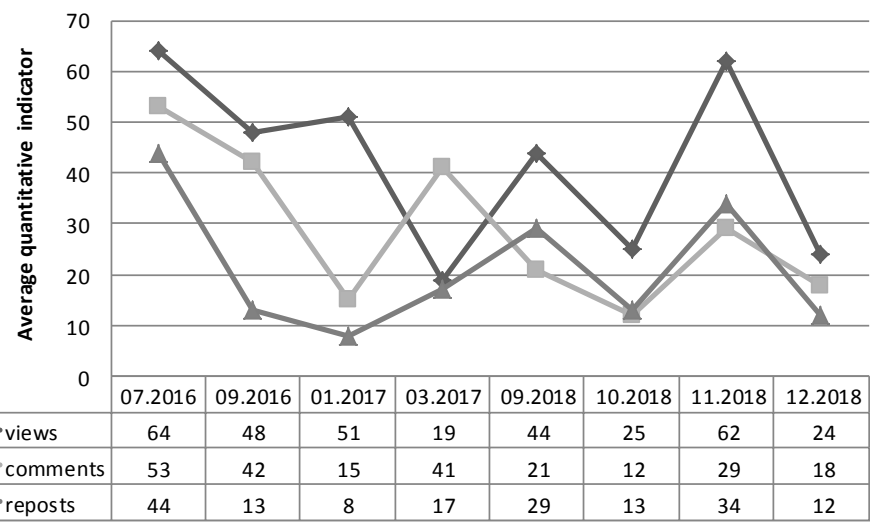


Therefore, the potential of social networks in the perspective of political mobilization is seen in the following:

- elimination of restrictions of any kind (territorial, temporal, organizational, psychological) regarding the intention of a person to participate in the political life of society;

- an opportunity to publicly and frankly state their own political position;

- overcoming personal isolation of citizens, on the one hand, and engagement of state authorities, on the other;

- promotion of effective interaction of ordinary citizens, leaders of public opinion, public people, institutional and non-associative unions, authorities and public administration, etc ;

- a sense of participation in a collective cause - and, as a result, emotional exaltation from the process.

The conducted research allows us to conclude that there is a formation and «maturing» of the politically active account owners on Facebook, capable of producing, selecting and disseminating politically oriented information, creating politically colored content and monitoring the transformational vicissitudes of the political process. In this case, the features of political mobilization available on the network are perceived as a necessary condition for the democratic transformation of society, which accompanies socio-cultural, institutional, political and legal changes. Of course, the effect of informational openness and public pressure on the authorities on solving certain problems is likely to cause a policy correction in a certain area, but it is unlikely that it will be substantial. Ukrainian experience shows that public activity is badly transformed into protest votes in the elections. Moreover, a significant part of public activists generally avoids real forms of political participation. As a rule, the effect of replacing a real political action with virtual «participation» is often very significant.

\section{REFERENCES}

1. Безрук О. О. Політична участь як чинник політичної мобілізації: теоретичний аспект [Електронний ресурс] // Сучасне суспільство. 2017. Вип. 1 (13). С. 16-24. Режим доступу: http://journals.hnpu.edu.ua/index.php/politology/article/view/213

2. Влияние через социальные сети / под общей ред. Е. Г. Алексеевой. Москва: Фонд «ФОКУС-МЕДИА», 2010. 200 с.

3. Гандалоева М. Т. Социальные медиа как социокультурный и политический феномен // Среднерусский вестник общественных наук. 2015. № 1(37). С. 18-24.

4. Іовчу Г. М. Політична участь громадян $€ С$ та України: порівняльний аналіз: автореферат дис. ... канд. політ. наук: 23.00.02 / Ганна Михайлівна Іовчу; Південноукраїнський національний педагогічний університет ім. К. Д. Ушинського. Одеса, 2011. 16 c.

5. Кремень Т. В. Политическая мобилизация: оъекты м субъекты // Историческая и социально-образовательная мысль. 2013. № 5 (21). С. 146-149.

6. Кремень Т. В. Політична мобілізація у контексті соціальніх медіа: автореферат дис. ... докт. політ. наук: 23.00.03 - політична культура та ідеологія / Кремень Тетяна Василівна; Національний педагогічний університет ім. М. П. Драгоманова. Київ, 2014. 38 с. 
7. Крестинина Е. С, Чернышов Ю. Г. Использование интернет-блогов и «социальных сетей» в российской публичной политике [Электронный ресурс]. - Режим доступа: https://cyberleninka.ru/article/v/ispolzovanie-internet-blogov-i-sotsialnyhsetey-v-rossiyskoy-publichnoy-politike

8. Політологія / А. Колодій, Л. Климанська, Я. Космина, В. Харченко. 2-ге вид., перероб. та доп. Київ: Ельга, Ніка-центр, 2003. 664 с.

9. Порпуліт О. О. Репрезентація дозвіллєвих практик в акаунтах українських користувачів мережі Facebook // Science and Education a New Dimension. Humanities and Social Sciences. 2017. V(23), Issue 139. P. 74-78.

10. Селезнев Р. С., Скрипак Е. И. Социальные сети как феномен информационного общества и специфика социальных связей в их бреде [Электронный ресурс] // Вестник Кемеровского государственного университета. 2013. № 2 (54), Том 3. C. $125-131$.

11. Соціологічні зрізи українського суспільства (моніторинг соціально-економічних очікувань населення: 2005-2014рр.): наукова доповідь / [Балакірєва O.M., Середа Ю.В., Дмитрук Д.А. та ін.]; НАН України; ДУ «Ін-т екон. та прогнозув. НАН України». Київ, 2015. 78 с.

12. Цимбалюк Н. М. Інституціональна модернізація культурно-дозвіллєвої сфери в Україні: автореф. ... докт. соціолог. наук : 22.00.04. - спеціальні та галузеві соціології / Цимбалюк Наталія Миколіївна. Київ, 2005. 34 с.

13. Чижик А. В. Сетевые коммуникации: вопрос влияния новых медиа на формирование общественного мнения // Коммуникология. 2017. Том 5, №3. С. 55-69.

14. Ямельницький О. Я. Політична мобілізація: до трактування поняття // Вісник Дніпропетровського університету. Серія: Філософія. Соціологія. Політологія. 2012. Т. 20, вип. 22 (3). С. $72-77$. 
Порпуліт 0

ISSN 2078-7324. Вісник Львівського університету. Серія Журналістика. 2019. Випуск 45

\title{
СОЦІАЛЬНІ МЕРЕЖІ ЯК ЧИННИК ПОЛІТИЧНОЇ МОБІЛІЗАЦІЇ
}

\author{
Олена Порпуліт \\ Одеський національний університет імені I. І. Мечникова, \\ вул. Дворянська, 2, 65082, Одеса, Україна \\ e-mail:porpulit@ukr.net \\ https://orcid.org/0000-0002-5118-305X
}

Стаття має за основу дослідження 200 акаунтів українських користувачів соціальної мережі Facebook, у два етапи: перший етап - протягом липня 2016 року, вересня 2016 року, січня 2017 року, березня 2017 року; другий етап - протягом вересня-грудня 2018 року. Воно зроблено для того, щоб відповісти на питання, до якої форми участі вдаються українці напередодні майбутніх президентських виборів, чи демонструють і в який спосіб громадяни беруть участь в політичних процесах країни, чи має місце в соціальних мережах факт політичної мобілізації. Проаналізовано на першому і другому етапах дослідження 2814 і 3015 повідомлень, розміщених у соціальній мережі Facebook, відповідно.

Досліджено, що участь українських громадян в політичних (громадсько-політичних) заходах зросла протягом досліджуваного періоду майже вдвічі. Згідно з поданими даними, найактивніше власники акаунтів мережі Facebook продукують текстові повідомлення, демонструючи політичну активність, висловлюючи прихильніть / незгоду з певними політичними тенденціями чи політичними процесами, долучаючись у такий спосіб до процесів політичної мобілізації тощо. Відзначено поступове зниження кількості переглядів, коментарів і перепостів, інформація про які подається поряд із «виступом» власника акаунта. Принциповим моментом вважаємо той факт, що з часом до акторів соціальних мереж приходить визнання за інтернет-ініціативами здатності до розпорошення громадського активізму, коли номінальна залученість стає лише імітацією суспільної ініціативи й «фальсифікацією» солідарних дій. При цьому наявні в мережі ознаки політичної мобілізації усвідомлюються як необхідна умова демократичної трансформації суспільства, яка супроводжує соціокультурні, інституційні, політико-правові зміни.

Ключові слова: соціальні мережі, акаунт, політична активність, політична мобілізація, дозволені практики. 